\title{
Q Axis Left Axis Deviation
}

National Cancer Institute

\section{Source}

National Cancer Institute. Q Axis Left Axis Deviation. NCI Thesaurus. Code C71094.

An electrocardiographic finding of the Q axis from -30 to -90 degrees. 